http://kitaibelia.unideb.hu/

ISSN 2064-4507 (Online) • ISSN 1219-9672 (Print)

(C) 2015, Department of Botany, University of Debrecen, Hungary

20 (2): 235-253.; 2015

DOI: $10.17542 /$ kit.20.235

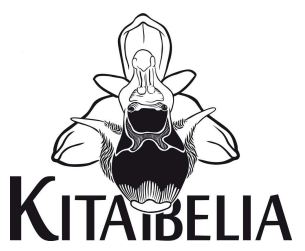

\title{
Adatok a Kisalföld flórájához és növényföldrajzához
}

\author{
KIRÁLY Gergely ${ }^{1 *}$, TAKÁCS Gábor² \& KIRÁLY Angéla³
}

(1) Nyugat-magyarországi Egyetem, Erdőművelési és Erdővédelmi Intézet, H-9400 Sopron, Ady E. u. 5.; *kiraly.gergely@emk.nyme.hu

(2) Fertő-Hanság Nemzeti Park Igazgatóság, H-9435 Sarród, Rév-Kócsagvár

(3) Nyugat-magyarországi Egyetem, Környezet- és Földtudományi Intézet, H-9400 Sopron, Ady E. u. 5.

\section{Data to the flora and geobotany of Kisalföld (Lesser Plain) region, NW Hungary}

Abstract - Lesser Plain (Kisalföld) - divided among three countries (Austria, Hungary and Slovakia) is the westernmost part of the lowland areas of the Pannonian Basin. Present paper provides a résumé of the authors' floristic work from the Hungarian part of the area, describing localities, habitats and regional phytogeography of 57 taxa altogether. The localities were listed according to the classification of small geographic regions. The most important results of the study are as follows:

- We recorded 5 species new to the region (Brachypodium rupestre, Bromus ramosus, Hypericum dubium, Lathyrus sphaericus, Tordylium maximum); all of them can be considered as submontanemontane elements.

- We reported several species new to a microregion within the Lesser Plain: montane species in the W-SW part of the Plain (Cirsium rivulare, Dryopteris dilatata, Equisetum telmateia), loess-connected species mainly on the Moson Plateau (Agropyron cristatum, Allium atroviolaceum, Euphorbia salicifolia, Viola ambigua); and occurrences of species on sandy soils near the Lake Fertő (Draba nemorosa, Stipa pennata).

- We explained the known localities of several salt tolerant species (e.g. Carex divisa, Crypsis alopecuroides, Juncus maritimus, Limonium gmelinii, Suaeda pannonica) from the Lake Fertő and its surroundings.

- We assessed the role of the forest management and nature conservational actions in the distribution of some important tree species (Acer tataricum, Betula pubescens, Fraxinus ornus, Quercus petraea, Salix pentandra).

- We discussed the regional nature conservational status of several protected and/or threatened species (e.g. Allium carinatum, Allium suaveolens, Carex strigosa, Hottonia palustris, Potamogeton coloratus, Stellaria palustris) in the Lesser Plain.

The activities of the authors in the surroundings of Győr were supported by monitoring results gained during the Hungarian Little Plain project (LIFE08 NAT/H/000289).

Keywords: floristic studies, geobotany, nature conservation, salt tolerant species, steppe flora

Összefoglaló - A Kisalföld flórája számos kistáj és növénycsoport tekintetében kifejezetten jól feltárt, de akadnak nagyon hiányosan ismert területei is, elsősorban a régió nyugati részén. A szerzők 20012014 közötti terepkutatásaik legfontosabb kisalföldi eredményeit adják közre a dolgozatban, amely 57 taxon adatait tartalmazza. A Kisalföld magyarországi oldalára új 5 faj (Brachypodium rupestre, Bromus ramosus, Hypericum dubium, Lathyrus sphaericus, Tordylium maximum) felfedezése. Számos faj egyes kistájakra nézve jelent újdonságot, a legtöbb ilyen adat azokról a kistájakról származik, amelyeket korábban alig vizsgáltak (Fertő-medence, Kapuvári-sík, Mosoni-sík). Nagy jelentőségűek a Fertőmedence egyes sziki fajaival kapcsolatos megfigyelések (Carex divisa, Crypsis schoenoides, Juncus maritimus, Suaeda pannonica, S. prostrata), mivel előfordulások a Fertő magyar oldalán tisztázatlan volt. A szerzők elemezték egyes fafajok (Acer tataricum, Fraxinus ornus, Quercus petraea) 
őshonosságának kérdéskörét a térségben, továbbá értékelést adtak egyes védett vagy veszélyeztetett fajok (pl. Allium carinatum, Allium suaveolens, Betula pubescens, Carex strigosa, Potamogeton coloratus, Stellaria palustris) aktuális természetvédelmi helyzetéről is.

Kulcsszavak: flórakutatás, növényföldrajz, sziki és erdőssztyep növényfajok, természetvédelem

\section{Bevezetés}

A Kisalföld flórája számos kistáj, valamint növénycsoport tekintetében kifejezetten jól feltárt, de akadnak nagyon hiányosan ismert területei is. A tájak közül kiválóan ismert Győr térsége PolGÁr (1941), majd közelmúltbeli szerzők (például RIEZING 2005, 2012a, SCHMIDT \& BAUER 2005, SCHмIDT 2007, 2010, 2011) munkái révén. A Szigetköz ZóLYOMI (1937), de még inkább az utóbbi három évtized vizsgálatainak (KEVEY 1989, 1993, 2001a, 2004a-c, 2008, WERNER 1990) köszönhetően hazánk egyik legjobban feltárt területe. A Hanság és a Fertő-medence flórájának ismerete döntően régi adatokra támaszkodik (ezek összefoglalását CSAPODY 1975 adja), mindkét terület esetében az országhatár közelsége évtizedekre befagyasztotta a terepi vizsgálatok lehetőségét. A Rábaköz flórája hiányosan ismert (JEANPLONG 1972, 1983, 1991 és KIRÁLY \& KIRÁLY 2005 közöl szórványadatokat), a Kisalföld Marcal menti déli nyúlványán csak az utóbbi 20 évben történtek behatóbb vizsgálatok (LÁJER 1997, 1998b). A Mosoni-síkról, kivéve a gyomflórát, egészen minimális archív és recens információ állt, áll rendelkezésre.

A vegetációs egységek vonatkozásában sokat tudunk a keleti Kisalföld erdőssztyepélőhelyeinek flórájáról, valamit jól feltártak az ottani szikesek maradványai. Ugyanez nem mondható el a nyugati Kisalföld hasonló élőhelyeiről. A lápok, láprétek flóráját a Hanságban ZólYOMI (1934) részletesen felmérte, újabban a Marcal mentén e tekintetben Lájer Konrád munkássága emelhető ki. Az erdők főleg a Szigetközben és térségében, Kevey Balázs több évtizedes munkájának köszönhetően kiválóan ismertek, de a rábaközi területekről viszonylag kevés adat állt rendelkezésre. Jól ismert az egész terület gyomflórája, e téren példaértékű összegzés PINKE \& PÁL (2001) dolgozata.

A szerzők 2001-2014 közötti terepkutatásaik legfontosabb kisalföldi eredményeit adják közre a dolgozatban, amelynek három fő célja van: egyrészt florisztikai érdekességeket (egyes tájakra új növényfajokat) mutatunk be, másrészt az élőhelyváltozásokkal összefüggésben a természetvédelmi szempontból jelentős fajok aktuális helyzetét értékeljük, végül számos faj esetében tárgyaljuk előfordulásai növényföldrajzi szerepét és kapcsolatait.

\section{Anyag és módszer}

A bemutatott fajok felsorolása alfabetikus sorrendű, az alkalmazott nevezéktan KIRÁLY (2009) munkáját veszi alapul. A lelőhelyek meghatározása a következő rendet követi: kistáj (DövÉNYI 2010 alapján, a tájnév rövidítve), községhatár, helyi név, élőhely, előfordulás jellege, megtaláló és évszám(ok), kvadrátazonosító. Egyes határhelyzetű lelőhelyek esetében mindkét szóba jöhető kistáj nevét megadtuk kötőjellel elválasztva. A fajok többsége esetében ellenőriztük a Magyar Természettudományi Múzeum, Budapest (a szövegben rövidítve: BP), egy esetben pedig a Debreceni Egyetem (DE) herbáriumi anyagát is.

\section{Alkalmazott rövidítések / Abbreviations used:}

Táfföldrajzi kistájak / Geographic regions (DöVÉNYI 2010 rendszere alapján):

CS - Csornai-sík; FM - Fertő-medence; GYT - Győr-Tatai-teraszvidék; HA - Hanság; IKM Igmánd-Kisbéri-medence; KS - Kapuvári-sík; MM - Marcal-medence; MS - Mosoni-sík; PDS - Pápa-Devecseri-sík; SZK - Szigetköz 
Adatközlők / Informants:

AA - Ambrus András (Sarród); BZ - Barina Zoltán (Budapest); KA - Király Angéla (Sopron); KG - Király Gergely (Sopron); LA - Lengyel Attila (Budapest); MA - Mesterházy Attila (Celldömölk); NA - Nagy Anikó (Sopron); PE - Pavol Eliaš jun. (Nitra, Slovakia); PGy - Pinke Gyula (Mosonmagyaróvár); SD - Schmidt Dávid (Sopron); TG - Takács Gábor (Sarród)

\section{Eredmények}

A dolgozatban 57 taxon (55 faj és 2 hibrid) adatai kerülnek közlésre a Kisalföldről (néhány fajnál a szomszédos területekről is szerepelnek kiegészítő adatok). A közlésre érdemes fajokat a Magyarországon őshonos taxonok közül válogattuk ki, az adventív elemeket kihagytuk a bemutatásból. Bár minden esetben törekedtünk arra, hogy adatainkat a Kisalföld egészét szemlélve értékeljük, nem hagyható figyelmen kívül, hogy az ausztriai és szlovákiai területek aktuális adatairól nincs teljes körű áttekintésünk. Adataink helymegadását a hazai tájföldrajzi beosztáshoz (DöVÉNYI 2010) kapcsoltuk. Ennek oka, hogy értelmezésünkben a növényföldrajzi Kisalföld területe majdnem mindenhol megegyezik a földrajzi Kisalföld nagytájjal. A „klasszikus határ” (amelyet számos korábbi szerző követ, így KÁRPÁTI 1958, 1960, Soó 1964, sőt, egy korai cikkünkben - KIRÁLY \& KIRÁLY 2000 - magunk is) JEANPLONG (1956) érvelését elfogadva öbölszerűen benyúlik a Répce-síkjára. Ez az álláspont geológiai, társulástani és chorológiai érvek alapján is támadható - részletes érvelést e tekintetben KIRÁLY et al. (2007) dolgozata tartalmaz. A földrajzi és növényföldrajzi határ egybeesését tekintve lényegi korrekciókat csak a Kemenesalja tekintetében javaslunk (itt csak a Celldömölk-Jánosháza-Gógánfa vonaltól keletre eső részeket tekintjük alföldi jellegűnek), e területet viszont mostani adatközlésünk nem érinti.

A lelőhelyadatok és a fajokkal kapcsolatos egyéb információk alapján a munkánk következő eredményeit tekintjük a legfontosabbnak:

- A Kisalföld hazai oldalának egészére új 5 faj megfigyelése. Közülük három bizonyosan a környező (Bromus ramosus, Hypericum dubium, Tordylium maximum), vagy távolabbi (Lathyrus sphaericus) domb- és hegyvidékekről leereszkedő, egy további faj (Brachypodium rupestre) elterjedési és élőhelyi viszonyai még országosan tisztázatlanok, de valószínűleg az utóbbi (távolabbról érkező) csoportba sorolható.

- Számos faj egyes tájakra nézve új, természetesen a legtöbb adat azokról a kistájakról származik, amelyeket korábban alig vizsgáltak (Fertő-medence, Kapuvári-sík, Mosonisík). Az adatok közül, növényföldrajzi jelentőségük miatt kiemelhetők a területre leereszkedő montán karakterú fajok (például Cirsium rivulare, Dryopteris dilatata, Equisetum telmateia), a kelet felé a Mosoni-síkig terjedő löszlakó erdőssztyep-fajok (Agropyron cristatum, Allium atroviolaceum, Euphorbia salicifolia, Viola ambigua), ill. a Kisalföld keleti feléig meglévő homoki fajok (például Draba nemorosa, Stipa pennata) előfordulásai.

- Több kevéssé ismert faj adatait a megvitatás és a tájékoztatás érdekében fejtettük ki bővebben (például Brachypodium rupestre, Bromus racemosus, Helictotrichon adsurgens), e fajokról országos szintủ az elterjedési és társulástani ismeretek hiánya.

- Különös súlyt fektettünk a Fertő-medence egyes sziki fajai (Carex divisa, Crypsis alopecuroides, C. schoenoides, Juncus maritimus, Suaeda pannonica, S. prostrata) előfordulásainak bemutatására, mivel több képviselőjük esetében a korábbi irodalom nem választotta el a hazai és az osztrák Fertő adatait. Jó néhány fajt (például Cyperus pannonicus, Ranunculus lateriflorus) úgy közölnek flóraműveink, hogy hiteles forrás sohasem említette őket a magyar oldalról.

- Tisztázni kívántuk egyes fafajok őshonosságának kérdését a Kisalföld különböző területein, kitérve az erdészeti telepítések hatására (Acer tataricum, Fraxinus ornus, 
Quercus petraea), illetve „újra felfedezett” fajok (Betula pubescens, Salix pentandra) egyes állományaira.

- A szerzők célja volt egyes védett fajok (például Allium carinatum, Juncus maritimus) természetvédelmi helyzetének elemzése. A dolgozat beszámol több, a térségből kipusztultnak vélt faj (például Betula pubescens, Potamogeton coloratus, Stellaria palustris) újrafelfedezéséről, valamint védett fajok (Allium suaveolens, Carex strigosa, Cirsium rivulare, Hottonia palustris) új lelőhelyeiről.

\section{Enumeráció}

Acer tataricum L. - KS: Bogyoszló Ny, Petlendi-erdő, keményfás ligeterdők magas cserjeszintjében és alsó lombszintjében, több erdőrészletben jelentős számban (KG, 2005) [8468.4]. KS: Bogyoszló K, Tölös-erdő több erdőrészletében, állományszerűen (KG, 2004) [8469.1, 8469.3]. - A faj kisalföldi (Szigetköz) és kapcsolódó nyugat-dunántúli (Fertőmelléki-dombsor, Ikva-sík) előfordulásairól KIRÁLY \& KIRÁLY (1999) részletes összefoglalást ad. Az ott felsorolt állományok őshonossága (a szigetközi kivételével) erősen megkérdőjelezhető, több helyen nagy valószínűséggel erdészeti alátelepítés eredményeképpen alakultak ki. Az újabb rábaközi előfordulások ugyan jó állapotú keményfás ligeterdőkben találhatók (amelyhez hasonló helyeken a Tiszai-Alföldön jellegzetes elem a faj), de itt is feltételezhetően szándékos betelepítés történt.

Agropyron cristatum (L.) Gaertn. - KS: Bősárkány, a vasútállomástól É-ra húzódó száraz rézsúkön (KG, 2004) [8369.1]. - A Kisalföld K-i felében nem ritka, közelítőleg összefüggő elterjedési területe Győrig tart, majd pontszerűen még a Szigetköz déli sarkában is megtalálható árvízvédelmi töltésen (SCHMIDT \& BAUER 2005, SCHMIDT 2010, RIEZING 2012a). A nagytáj középső és nyugati részéről viszont nem volt ismert előfordulása hazai területen. PILL (1916) szerint a Fertő körül „mindenütt előfordul”, ez valójában csak a tó északiészakkeleti peremének kisebb platóira és kiemelkedéseire lehetett igaz (vö. JANCHEN 1977), ahol ma már nagyon ritka (KäSTNER \& FISCHER 2008). A bősárkányi lelőhelyen a térségben érdekességnek számító száraz gyepi fajokkal (például Nigella arvensis, Potentilla inclinata, Thymelaea passerina, Vicia pannonica subsp. pannonica) együtt mutatkozik.

Allium atroviolaceum Boiss. - MS: Várbalog DK, a Jánossomorja felé vezető közút füves árkán, 2 virágzó tő (KG, 2013) [8168.3]. - Balkáni-elő-ázsiai faj, nyugati elterjedési határa Magyarországon át húzódik. A Nagyalföld egyes részein és a Dunántúli-középhegységben igen szórványos, ill. van egy kérdéses soproni adata (Soó 1973). A hazai Kisalföldről korábban a Szigetközből jelezték (Dunaszeg, legelő, KEVEY 2001a), a lelőhelyet később felszántották, s a faj valószínúleg eltűnt innét (KEvEY ex litt.). Ezen kívül ismert egy közelmúltban gyűjtött herbáriumi példány Tát mellől (Barina Z., 2001, BP362575). Ausztriában a közelmúltban került elő egy Soprontól É-ra fekvő dombvidéki területen, Nagymarton (Rohrbach) mellett (FISCHER \& NIKLFELD 2001). Szlovákiában a Kisalföld keleti peremén néhány lelőhelye ismert (SOMOGYI 2001).

Allium carinatum L. - HA: Lébény Ny, a Tárnokréti felé vezető közút K-i oldalán, kiterjedt kékperjés-mocsárrét komplexumban (KG, 2007) [8270.3]; Újrónafó, Vesszős-erdő É-i oldalán fekvő kékperjés réten (KG - TG, 2004) [8269.2]. - Az 1990-es évekig ritkaságként számon tartott faj dunántúli lelőhelyei számottevően megszaporodtak, a Nyugat-magyarországi peremvidékről KIRÁLY et al. $(2004,2007)$ mintegy 25 recens adatát publikálták. A Kisalföldön csupán néhány korábbi megfigyelése ismert (ZóLYOMI 1931a: Mosonszentjános; PolGár 1941 Győr környéki adatai nem síkvidékiek), majd KIRÁLY ap. FARKAS (1999) a tóközi Fehértó határából jelezte.

Allium rotundum L. - KS: Vág É, Vági-halom, a Szil felé vezető út derékszögú kanyarjában, füves útszélen, többtucat tő (KG, 2004) [8569.1]. MS: Várbalog DK, a volt határőrlaktanya 
közelében a közút füves árkán néhány tő (KA - KG, 2004) [8168.4]. - A fajnak több régi Győr környéki adata ismert (PoLGÁr 1941, BP: 5 lelőhelyről származó gyűjtések), újabban RIEZING (2012a) Ács környékén találta, Barina Zoltán pedig a régió keleti felében gyűjtötte (2001, Tát, BP635279). A Kisalföld déli és nyugati részén a felsoroltak az első megfigyelései.

Allium suaveolens Jacq. - FM: Hidegség K, leromlott kékperjés réten, 3 virágzó tő (KG, 2008) [8366.4]. - Kékperjés láprétek eltúnőben lévő növénye. A Kisalföldön a Hanságban, Győrszemere mellett és Tata térségében fordul elő, ezen kívül ismert a síkság pereméhez közel Sopronkőhidánál (GÁYER \& POLGÁR 1926, CSAPODY 1975, RIEZING 2002, BARINA 2003, SCHMIDT 2011), a kapcsolódó burgenlandi területekről hiányzik (JANCHEN 1977). Megtalálása a Fertő-medence területén váratlan fejlemény, mivel a tó hazai oldalán csupán néhány elszigetelt, erősen átalakult kékperjés rét található. A lelőhelyen az egyedüli érdekesebb kísérőfaj az Allium angulosum volt.

Arctium nemorosum Lej. et Court. - SZK: Ásványráró, Halrekesztő zárás alatti ág partján, magaskórós ligeterdő-szegélyben (KG - KA - PGy, 2007) [8171.3]. - Magyarországon szórványos faj, amely üde és nedves erdőszegélyekben, magaskórósokban, vágásnövényzetben él. A Szigetközből (egyetlen kisalföldi jelzésként) egy mikológiai dolgozatban (FoDOR et al. 2002) közölték, a régióban gyűjtött herbáriumi példányai nem ismertek. A jelzett dolgozat a fajt a tájegység keményfás ligeterdeiben (konkrét lelőhely említése nélkül) általánosan jellemzőnek vélte, viszont az itteni erdőtársulások monografikus feldolgozásaiban (KEVEY 2002, 2004a,b) nincs nyoma. Így kétséges, hogy a szerzők valóban e nehezen határozható fajt találták meg. A Kisalföld széléhez közel Sopron térségében ismerjük (KIRÁLY et al. 2004).

Aster tripolium L. subsp. pannonicus (Jacq.) Soó - MS: Mosonmagyaróvár, M1 autópálya, Lajta pihenő (KG 2013) [8169.4]. - A Fertô-medence szikes élóhelyein gyakori, sőt, itt előfordul télisásos-nádas élőhelyeken és csatornapartokon is. Ugyancsak megtalálható Győr körül, bár itt élettere erősen beszűkült (SCHMIDT 2007). Iván környéki előfordulásai már a Kisalföldön kívül, a Répce-síkon vannak (KIRÁLY et al. 2007). A Mosoni-síkon természetes élőhelye gyakorlatilag nincs, a most megtalált előfordulás más, autópálya mellett terjedő sótürő fajokéhoz (például Plantago maritima, Spergularia salina) hasonlóan másodlagos.

Betula pubescens Ehrh. - HA: Károlyháza, Vesszős-erdő É-i része, spontán puhafás sűrüségben, láposodó égeres szélén néhány középkorú fa (KG - TG, 2012) [8169.4]. - A hansági lápterületen a korábban Mosontarcsa (ma: Andau), majd a határváltozás miatt Mosonszentjános községhatárához tartozó területen szép lápi állománya („Nyíres”) volt ismert (ZóLYOMI 1934), amely az 1950-es években teljesen megsemmisült. Bár CSAPODY (1975) félreérthetően fogalmaz az állomány meglétéről, a fajnak az 1930-as évek óta nem volt hitelt érdemlő hansági (egyben kisalföldi) megfigyelése (KIRÁLY \& KIRÁLY 2010). Egykori élőhelyén ma homogén nemesnyárasok állnak, a lecsapolás és tereprendezések a termőhelyet is végérvényesen tönkretették. Az ún. Észak-Hanság (Lébénytől Ny-ra fekvő medencerész) egyes égeres-nyíreseiben sejthető volt a faj megmaradása, de évtizedes keresés után sem került elő, így nagy meglepetésként hatott a Vesszős-erdőben megtalált apró állomány. E területrész az Észak-Hanság viszonylag zárt, termőhelyi viszonyaiban kevésbé leromlott része, így van remény a faj fennmaradására.

Brachypodium rupestre (Host) Roem. et Schult. - CS: Sobor ÉK, a Rába védőtöltésén, másodlagos gyepben (KG, 2004) [8570.1]. FM: Fertóhomok É, a Palatinus-csatorna melletti félszáraz gyepben (KG, 2008) [8366.4]; Hegykő É, kékperjés rét szegélyében, a fertői télisásos-nádas öv közelében (KG - PE, 2012) [8366.2]; Hidegség, a falu K-i peremén fekvő kékperjés réten (KG, 2006) [8366.3]. - A Brachypodium pinnatum-csoportba tartozó taxon, amelynek adatai a korábbi hazai flóraművekben igen hiányosak, korábban alkalmazott 
határozóbélyegei pedig nem világosak (lásd például Soó 1973, SIMON 2000). PENKSZA \& KIRÁLY (2009) a külföldi példák alapján egyértelműsítette a magyar határozókulcsot, de a csoport átfogó hazai herbáriumi revíziója még nem történt meg. Az első szerző tapasztalatai alapján a $B$. rupestre a Balkán-félsziget és Keleti-Alpok szubmontán-montán területein, meszes alapkőzeteken sokfelé gyakori társulásalkotó (eltérően a B. pinnatum hazai, cseres-tölgyes övhöz kötődő előfordulási centrumától); kisszámú, biztosan azonosított magyarországi előfordulást azonban nehéz tipizálni. A Fertő déli partján ismert állományok egy része viszonylag degradált gyepekben található, s nem zárható ki, hogy (legalább egyes helyekre) úgy hurcolták be. Mindenesetre a fajt korábban nem jelezték a Kisalföldről, sőt, valószínúleg régebbi nagyalföldi jelzései is tévesek (lásd Soó 1973 értékelését is).

Bromus racemosus L. - CS: Egyed DNy, Emma-dűlő, a Buga-csatorna menti jellegtelen üde réteken (KG, 2004) [8469.4]. KS: Bogyoszló Ny, a Petlendi-erdő É-i szélén fekvő réteken (BZ - NA - KG, 2003) [8468.2]; Pásztori DNy, a Szilsárkány felé vezető út menti réteken (KG, 2014) [8469.2]. - A hazai pázsitfüvek egyik alig ismert képviselője, elterjedéséről kevés információ áll rendelkezésre. Az adathiányhoz hozzájárul, hogy a faj kimaradt SIMON (1992, 2000) Bromus-kulcsaiból, holott a korábbi hazai határozókban szerepelt. Soó (1973) eleve kisszámú hazai jelzését „nagyrészt kétesnek” vélte, ezen belül két kisalföldi adatot sorolt fel (Győr, Celldömölk). Előbbi bizonyára PolGÁr (1941) kismegyeri lelőhelyét fedi, itteni előfordulását herbáriumi lap is megerősíti: (Polgár S., 1909, BP268127), sőt, van egy közöletlen gyűjtése is Győrből, a Marcal mellől (Polgár S., 1921, BP268128). Tapasztalataink szerint valóban nem gyakori országos szinten, de különösebben ritkának sem nevezhető. A hasonló rokonfajokkal ellentétben a viszonylag jó állapotú (rendesen mocsárrét-eredetű) üde rétek növénye, ruderális tendencia nélkül (ellentétben a morfológiailag hasonló $B$. commutatus, B. hordeaceus fajokkal). Ez a vélemény nagy vonalakban megegyezik Soó (1980) nézeteivel, míg a Soó (1973) által jelzett magassásos társulásokat nehezen tudjuk élőhelyeként elképzelni. A Kisalföldön a Rábaköz kötött talajú rétjein találtuk, itt jellemző kísérő fajai az Anthoxanthum odoratum, Briza media, Festuca arundinacea, Helictotrichon pubescens, Ononis arvensis, Rhinanthus minor, Serratula tinctoria.

Bromus ramosus Huds. - CS: Maglóca, Sziget-erdő, nitrofil gyertyános-tölgyesben (KG, 2004) [8369.2]. - Határozottan montán jellegü faj, amelyet korábban nem választottak el a B. benekenii-től, így (vö. Soó 1973) herbáriumi alap nélküli régi adatai bizonytalanok. Soó (1980) és SIMON (2000) kisalföldi lelőhelyét nem jelezték. Bár tipikus hazai előfordulásai a bükkösökhöz és szubmontán gyertyános-kocsánytalan tölgyesekhez kötődnek, akadnak kivételek, így a maglócaihoz hasonló körülmények között (Vitnyédnél, már a Répce-síkon) előfordul keményfás ligeterdőben is (KIRÁLY et al. 2007).

Bupleurum falcatum L. - FM: Hegykő É, a Fertőhöz vezető kavicsút mellett, kőrises erdősáv szegélyében (KG, 2003) [8366.4]; Hidegség ÉNy, száraz gyepfragmentum a volt határsávban (KG, 2008) [8366.3]. MS: Hegyeshalom, Márialiget, az A25 határpont mellett, határsávi félszáraz gyepben (KA - KG, 2009) [8068.2]. - Középhegységi és dombvidéki melegkedvelő erdők növénye, amelynek a Kisalföldön kevés potenciális élőhelye, s ehhez kapcsolódóan kisszámú adata ismert. PoLGÁr (1941) a Pápa-Devecseri-sík É-i pereméről és a Mosoni-sík széléről (Kunsziget), Soó (1966) Bősárkányból, míg (egyedüli recens előfordulásként) SCHMIDT \& BAUER (2005) Győrság mellől jelzik. A Fertő-medencéből korábban ismeretlen volt, új lelőhelyeire bizonnyal a Fertőmelléki-dombsorról telepedhetett be, ahol gyakori, jellegzetes faj.

Calamagrostis canescens (Weber ex Wigg.) Roth - CS: Barbacs, a Barbacsi-tó D-i szegélyében, magassásos-nádasban több folton társulásalkotó (KG - TG, 2010) [8369.4]. FM: Fertőboz K, a Bozi-csatorna közelében, nádas-rekettyefüzesben, kis telep (KG, 2008) [8366.3]. HA: Kapuvár, Miklósmajor DK, magassásos-égeresben (KG, 2004) [8368.1]; 
Kapuvár, Miklósmajor É, füzes-nyáras kubikgödörben (KG, 2004) [8368.1]; Kapuvár, Királytó DK, magassásos-füzesben nagy telepek (KG, 2004) [8368.2]; Újrónafó, Vesszőserdő, magassásos-égerlápban kis telepek (KG - TG, 2006) [8269.2]. KS: Rábatamási DNy, régi, feltöltődött kavicstó spontán füzesében néhány m²$^{2}$-en (BZ - KG - NA, 2003) [8468.2]; Szárföld K, a vasúttól D-re, a vasút régi, magassásos árkában több kis telep (KG, 2010) [8468.2]. - Rekettyefüzesek és égeresek, magassásos holtmedrek ősi lápi növénye, amelynek korábban viszonylag sok előfordulását ismerték. Hansági adatait CSAPODY (1975) összegzi, a Szigetközből régi (ZólYomi 1937, PolGÁR 1941) és újabb szerzők (KEveY \& ALEXAY 1994) egyaránt jelzik, ezen kívül PolGÁR (1941) a Rába mentén is megtalálta Győr közelében. Általunk gyưjtött adatait a leltározás szándékával soroljuk fel a Hanságból, ahol ma már florisztikai ritkasággá vált. Más tájegységeken (Fertő-medence, Kapuvári-sík) előfordulása új, de ez nyilván nem terjedését jelenti, hanem az utolsó mikropopulációk felfedezését az intenzív flórakutatásnak köszönhetően.

Cardamine parviflora L. - HA: Acsalag É, a falutól a Rábca felé eső nedves-belvizes szántókon (KG, 2004) [8369.1]; Kapuvár, Királytó térségében fekvő üde és nedves réteken gyakori (KG, 2004) [8368.1, 8368.2]. KS: Bogyoszló Ny, Petlendi-erdő, tócsán (KG, 2005) [8468.4]. - A Kisalföldről egy régi adatát találtuk a Csornai-sík tóközi részéről (Barbacsi-tó, POLGÁr 1941), egyetlen burgenlandi adata (Mosontarcsa = Andau mellett, JANCHEN 1977) pedig hansági. Korábbi dolgozatunkban (KIRÁLY et al. 2007) általánosságban írtuk, hogy „a Hanság egyes rétjein ... tömeges", a pontosítás kedvéért most részletesen közöljük adatait. Valójában csak egy, de nagy $\left(>2 \mathrm{~km}^{2}\right)$ kiterjedésű rétkomplexumban, a Királytó térségében fordul elő nagy számban, többi előfordulása jelentéktelenebb.

Carex divisa Huds. - FM: Fertőd É, a Peregház közelében, nedves réten (KG, 2012) [8367.3]; Fertôszéplak és Sarród, a Lászlómajortól Ny-ra, a Körgáttól D-re fekvő, legeltetett szikes réttömbben elszórtan sokfelé (KG, 2004-2014) [8366.2, 8367.1]; Sarród, Nyárliget É, az országhatár közelében, egykori kavicstó (ma horgásztó) partján (KG, 2006) [8367.1]. Szikesedő mocsár- és láprétek növénye, amelyet a korábbi szerzők a hazai Kisalföld több pontjáról jeleztek (Fertő-medence: Balf - WALLNER 1903; Győr környéki szikesek - PoLGÁR 1941; hansági adata - KORNHUBER 1885 - feltehetően határon túli, burgenlandi területre vonatkozik). Győrtől K-re több recens adata van (SCHMIDT 2007, 2010, RiEzinG 2012a), illetve LÁjER (1998a) a Marcal-medence D-i peremén is megtalálta. A Fertő hazai részéről újabb publikált adatát nem találtuk (csak egy herbáriumi példányt Sarródról: Somlyay L., 1995, BP618588), a fenti felsorolás a területen általunk ismert lelőhelyeit összegzi.

Carex elongata L. - HA: Csorna, Földsziget, Csíkos-éger, égerlápban (KG, 2006-2010) [8368.2]. KS: Hövej ÉNy, Kardos-ér mellett, „Irtás”, kőrises ligeterdőben (KG, 2005) [8468.1]. - Korábban a Hanság égerlápjainak karakterisztikus faja volt (adatainak összegzését lásd CSAPODY 1975 monográfiájában), az újabb felmérések során itt csak egy helyen került elő (Csíkos-éger, itt LÁjER 1998b is jelzi előfordulását). A höveji lelőhelyen Carex remota, C. strigosa, Cnidium dubium, Filipendula ulmaria társaságában, a rábaközi térségben unikálisnak számító élőhelyen fordul elő.

Carex hostiana DC. - FM: Fertőhomok É, a Homoki-csatorna mellett, kékperjés réten (KG TG, 2006) [8366.4]; Hidegség, a falu K-i peremén fekvő kékperjés réten (KG, 2006) [8366.3]. - A Kisalföldön Győr környékén (PolGÁR 1941, SCHMidT 2011, RiEZING 2012a), valamint a Marcal-medencében (LÁJER 1997) elég sok adata ismert nedvesebb kékperjés rétekről, továbbá a Nyugat-magyarországi peremvidék kisalföldi szegélyében is több helyen előfordul (KIRÁLY et al. 2007). A Fertő mellől WALLnER (1903) közelebbi helymegjelölés nélkül említi. Érdekes módon a Hanságból eddig nem jelezték.

Carex strigosa Huds. - KS: Bogyoszló Ny, Petlendi-erdő, keményfás ligeterdőben, ill. erdei út tócsáin (KG, 2005) [8468.4]; Himod K, Miklósmajortól D-re fekvő keményfás ligeterdőben („Alsó-erdő”) több tucat példány (KA - KG, 2002-2014) [8468.3]; Hövej ÉNy, Kardos-ér 
mellett, „Irtás”, kőrises ligeterdőben 20-30 tő (KG, 2005) [8468.1]. - A Kisalföld DNy-i peremén a Répce menti ligeterdőkben a közelmúltban erős állományai kerültek elő, ill. van egy régi szigetközi említése is (KIRÁlY \& KirálY 2000, KeveY 2001a). A most felsorolt előfordulások kiegészítést jelentenek a Rábaköz keleti peremén található lelőhelyekhez.

Catabrosa aquatica (L.) P. B. - KS: Répcelak, Répce-árapasztó a vasúti hídtól Ny-ra kb. 1 km-re, parti növényzetben (KG - MA, 2003-2007) [8568.3]. - A hazai Kisalföldről mindössze három régi, ill. egy recens megfigyelésre találtunk adatot: Balf (Fertő-part) (Szontagh 1864), Győrújbarát (SchmidT \& BAUER 2005), Mezőörs (Polgár 1941), Tata (Polgár S., 1929, BP236434), ezért fontosnak tartjuk megemlíteni fenti lelőhelyet, ahol Berula erecta, Glyceria notata és Veronica anagallis-aquatica társaságában fordul elő.

Cephalaria transsylvanica (L.) Schrad. - CS: Árpás, Kálmánmajor, a Rábapordány felé vezető út mellett, füves útszélen (KG, 2006) [8470.3]. MS: Várbalog, a falutól Mosonszentpéter felé vezető közút mentén, száraz gyepfragmentumokban több helyen (KA - KG, 2005-2013) [8168.3, 8168.4]. - A Kisalföld Győr megyei részén PoLGÁr (1941) még közönségesnek írta, SCHMIDT \& BAUER (2005) több mint 10 lelőhelyen találták meg, a legnyugatabbiak Győr belterületén a Rába bal partján, ill. a Szigetköz csücskén helyezkednek el. A Kisalföldtől D-re, a Nyugat-Dunántúlon egyedüli stabil előfordulásként a Kemeneshát tufakibukkanásain nagy állományai vannak (MESTERHÁzy et al. 2003). Ausztriában ritka, csak az ÉK-i „pannon” területeken fordul elő, rövid életű populációkkal (KÄSTNER \& FISCHER 2006). A Mosoni-sík hazai oldalán állományai életerősnek tűnnek, e lelőhelyeken ismételten megtaláltuk.

Cirsium palustre (L.) Scop. - FM: Fertóboz, a falu alatti üde lápréten (AA - KG - TG, 2009) [8366.3]; FM: Hidegség ÉNy, üde láprét-folton (KG, 2008) [8366.3]. - A Kisalföldön a Hanságban, Szigetközben és a Pápa-Devecseri-síkon régóta ismert (vö. ZólYOMI 1934, Polgár 1941, CSAPODY 1975, WERNER 1990), bár sehol sem gyakori. A Nyugat-Dunántúl acidofil talajú vágásain, erdőszélein nem ritka, a Soproni-hegységben kifejezetten jellemző; a Fertő-medencébe (ahonnét csak egy régi adatát ismerjük Balf és Fertőrákos között, CSAPODY 1975) bizonyára innét érkezett.

Cirsium rivulare (Jacq.) All. - FM: Hidegség, a falu K-i peremén fekvő, kékperjés rétbe illeszkedő magaskórós üde lápréten (KG, 2006) [8366.3]. - A Hanság és a Marcal-medence láprétjein egykor jellemző faj volt, ma megfogyva, de még megtalálható e területeken (ZÓLYOMI 1934, POLGÁR 1941, CSAPODY 1975, LÁJER 1997), sőt, a Szigetközből (WERNER 1990) és Győrszemere mellől (SCHMIDT 2011) is előkerült. A Fertő-medencéből nem találtuk korábbi adatát, hidegségi lelőhelye (a hasonló fertőbozival együtt) a medence üde láprétjeinek utolsó, apró, de jó állapotú képviselője.

Cnidium dubium (Schkuhr) Thell. - HA: Lébény Ny, a Tárnokréti felé vezető közút mindkét oldalán, kiterjedt kékperjés-mocsárrét társulásokban (KG, 2012) [8270.3]; Lébény $\mathrm{Ny}$, a volt Ottómajor térségében fekvő rétkomplexumban (KG - TG, 2014) [8269.2]; Lébény Ny, Pintér-Hany, égeresek közötti zárvány réten (KG - TG, 2012) [8269.4]; Újrónafó, Vesszőserdő É-i oldalán fekvő kékperjés réten (KG - TG, 2004) [8269.2]. KS: Bogyoszló K, a falutól 3 km-re, nagy kiterjedésű mocsárréti tömbben (KG, 2004) [8469.1]; Hövej ÉNy, Kardos-ér mellett, „Irtás”, kőrises ligeterdő szélén (KG, 2005) [8468.1]; Jobaháza Ny, a falutól 1 km-re, leromlott mocsárréten (KG, 2004) [8469.3]; Sopronnémeti K, a Szilsárkány felé vezető út mellett, csatornaparton (KG, 2004) [8469.1]; Szany, Éger-erdő D-i része, tisztáson (KG MA, 2003) [8569.2]. - A jó vízellátottságú mocsár- és láprétek jellemző fajaként számon tartott növény hazai előfordulási centruma a Kisalföld középső része. A területről többi régi adatát ismerjük a Hanságból, néhányat a Rábaközből és Győr térségéből (ZóLYOMI 1934, PolGár 1941, SCHMIDT 2010, RIEZING 2012a). Fenti adatait növényföldrajzi és természetvédelmi jelentősége miatt soroltuk fel. Az általunk ismert állományok mocsár- és lápréti vonásokat egyaránt hordozó kaszálóréteken élnek (Achillea asplenifolia, Carex panicea, 
Festuca arundinacea, Gratiola officinalis, Selinum carvifolia, Succisa pratensis kísérőfajokkal), amelyeken a gazdálkodás felhagyása után akár még évtizedekig előfordulhat a faj, a magaskórósodást-cserjésedést ugyanis kifejezetten jól viseli.

Crypsis alopecuroides (Piller et Mitterp.) Schrad. - KS: Farád, Csorna felé a 85 sz. úttól Dre, szántóföldi belvízen néhány tő (KG, 2010) [8369.3]; KS: Osli DK, belvizes kukoricásban, egyetlen tő (KG 2006) [8368.4]. - Szikes tófenék- és iszaptársulások növénye, amely felbukkanhat nedves parlagokon és földutak kocsinyomain is. A nagy hazai flóraművek a faj alföldi előfordulását általánosságban említik, de kisalföldi előfordulását csak PoLGÁR (1941, ill. néhány lapja a DE gyüjteményben) jelezte a Győr környéki szikesekről. E területen az újabb kutatások során már nem találták meg (SCHMIDT 2007). Szlovákiában csak a Kisalföld középső és K-i felén fordul elő (Holub \& GRULICH 1999, Eliâš et al. 2011). A Fertő mellett PILL (1916) a tó partjáról általánosságban említi, JANCHEN (1977) a régi lelőhelyekre utal, s megjegyzi, hogy a Tószögből (Seewinkel) hiányzik. A Fertő hazai oldaláról egyértelmű jelzése nincs, bár CSAPODY (1975) Szontagh-nak tulajdonít egy fertőrákosi adatot, valójában SzONTAGH (1864) csak Oggau mellől jelezte. A felsorolt recens adatok a Kapuvári-sík két pontján csupán időszakos felbukkanását jelentik, stabil állománya nincs a térségben. Mindkét helyen különösebb szikes jelleg nélküli szántóföldi belvízen került elő, Alisma lanceolatum, Atriplex prostrata, Lythrum hyssopifolia, Potentilla supina társaságában.

Crypsis schoenoides (L.) Lam. - FM: Hegykő É, a fertői nádas peremén futó földút tócsáin (KG, 2008) [8366.4]; Sarród, Fertőújlak, Borsodi-dűlő, kiszáradt szikes tófenék, az egyes években változó mennyiségben (KG, 2008-2009) [8367.1]; Sarród, Fertőújlak, „Cikes” legelő mellett, nedves parlagon (KG, 2004, 2008) [8267.3]; Sarród É, Lászlómajortól D-re, nedves parlagon (KG, 2008) [8367.1]. - Az előzőhöz hasonló karakterű, de a Kisalföldön elterjedtebb és (legalábbis regionálisan) a szikes élőhelyekhez szorosabban kötődő faj, megvan a Dunától É-ra is (ELIÁš et al. 2008). A hazai oldalon PolGÁR (1941) a Győrtől DK-re fekvő szikes fragmentumokon még gyakorinak találta, újabban csak néhány lelőhelye ismert (SCHMIDT \& BAUER 2005, SCHMIDT 2007, 2010). A Fertő-medence tószögi részén több helyről jelezték (JANCHEN 1977), magyar területről viszont nincs korábbi adata (BP gyűjteményben is csak burgenlandi gyűjtéseit találtuk). Sarródnál (Borsodi-dűlő) a kiszáradó tófenék vegetációban rendszeresen megfigyelhető, többi előfordulása rövid életű belvizekről és tócsákról került elő. Ezen kívül érdekes megjelenése ismert a Sopronimedencében (már Nyugat-Dunántúl, KIRÁLY et al. 2005).

Cystopteris fragilis Bernh. ex Schrad - PDS: Takácsi, a katolikus templom kőfalán, a tömeges Asplenium trichomanes mellett néhány tő (KG, 2005) [8570.4]. - A Kisalföldön két korábbi adata ismert ZólYOMI (1931b) dolgozatából (Hanság, Csíkos-éger, Rábaköz: Répcelak, vasúti híd lábazatán). A Pápa-Devecseri-síkon nem találtuk említését.

Draba nemorosa L. - FM: Fertőszéplak É, „Széplaki-legelő”, lapos homokdomb jellegtelen száraz gyepjeiben (KG, 2004-2013) [8366.4, 8367.3]. HA: Kapuvár, Tőzeggyármajor D, az Ikva töltésén (KG, 2004) [8367.2]. - A Kisalföldön a Győr környéki homokterületeken számos régi említése ismert (vö. PoLGÁR 1941), itt ma is gyakori több homoki gyeptípusban. A Fertő-medence hazai oldaláról korábban nem jelezték, a Hanságban egy kapuvári adatáról tudunk (CSAPODY ap. KIRÁLY \& KIRÁLY 1999). Az osztrák térfélen a Tószögben (Seewinkel) és a Hanságban is előfordul (vö. JANCHEN 1977).

Dryopteris dilatata (Hoffm.) A. Gray - PDS: Pápa É, Pálházapuszta mellett, telepített feketefenyvesben, Dryopteris carthusiana és Galium odoratum kísérőfajokkal (KG, 2005) [8670.2]. - A térségben ritka páfrányfaj, egyedül a Hanság égereseiben ismertek jelentősebb állományai (régi adatait CSAPODY 1975 foglalja össze; a tájon ma is megvan), ezen kívül a Szigetközben és Győrszentiván mellett került elő (WERNER 1990), a Kisalföld déli feléből nem találtuk adatát. 
Equisetum telmateia Ehrh. - KS: Beled D, az elkerülő úttól D-re fekvő kavicstó cserjés gátján nagy telep (KG, 2003) [8568.2]. - A Kisalföldről régi szigetközi említéséről tudunk (Soó \& JÁVORKA 1951). Az új rábaközi előfordulás eredete kérdéses, lehetséges, hogy spontán betelepülés, de nem zárható ki, hogy a tó töltésanyagával hurcolták be. A szomszédos nyugatdunántúli területeken (például az Ikva-síkon és a Répce-sík keleti sávjában) nem fordul elő.

Euphorbia lucida W. et K. - CS: Enese K, a vasútvonaltól D-re fekvő kékperjésekben (egykori kubikgödrök helyén) (KG, 2012) [8370.4]; Kóny és Dör között, a vasútvonaltól D-re fekvő nagy magassásos réteken (KG, 2012) [8369.4, 8370.3]. KS: Pásztori É, a Linkó-árok mellett (KG - NA, 2004) [8469.2]; Szany, Éger-erdő D-i része, fiatalosban, több tucat tő (KG, 2003) [8569.2]; Szilsárkány ÉK, a Szilsárkányi-Alsó-csatorna mentén (KG, 2004) [8469.4]. PDS: Káptalanfa DNy, Besenyő, homoki legelők közötti láprét-magassásos komplexum (KG - MA, 2007) [8969.2]. SZK: Győr, Kisbácsa K, a Mosoni-Duna közelében fekvő nedves homokterületen (KG, 2008) [8271.4]. - A Kisalföld keleti felében, főleg ártéri réteken szórványosan előforduló faj, legnyugatabbi adatai a hazai oldalon Győr közelében a Rába mentén, ill. a Szigetközben ismertek (vö. PolGÁR 1941); újabb publikált adata egész kevés van (például BARINA 2003). A Kisalföld nyugati részén egyetlen bizonytalan, régi jelzésről tudunk („a Fertőnél”, SzONTAGH 1864). A síkság peremén egy szigetszerű adatát a közelmúltban közöltük a Nyugat-Dunántúlról is (Hegyfalu, KIRÁLY et al. 2007). A most közölt adatok a Kisalföld újabb tájegységeiről bizonyítják igen szórványos előfordulását. A lelőhelyeken főleg kötött talajú magassásos társulásokban került elő, érdekesebb kísérői Carex disticha, Euphorbia palustris, Lycopus exaltatus, Scutellaria hastifolia, Serratula tinctoria, Thalictrum lucidum voltak.

Euphorbia salicifolia Host - MS: Rajka, Márialiget ÉNy, határsáv az A22 határkő térségében, cserjés gyepekben [KA - KG, 2010) [8068.2]. - Löszös száraz gyepek, legelők, erdőszegélyek növénye, ami a Középhegység hegylábain és a Nagyalföld egyes tájain nem ritka, a Kisalföldről azonban csak néhány adata ismert a Győrtől K-re elterülő homokvidéken (POLGÁR 1941, SCHMIDT \& BAUER 2005). A Mosoni-sík új határszéli lelőhelye elszigeteltnek tűnhet, de a határ túloldalán, a Pándorfi-síkon (Pandorfer Platte, több jelentős sztyepfaj, például Arenaria procera, Artemisia pancicii, Prunus tenella lelőhelye) szintén előfordul - a hazai lelőhely (ahol Brachypodium pinnatum, Centaurea scabiosa, Seseli varium, Teucrium chamaedyrs társaságában található) inkább ehhez csatlakozik.

Fraxinus ornus L. - CS: Csorna DK, Hercegszeri-erdő, keményfás-ligeterdő származékában, számos példány (KG - NA, 2004) [8469.2]. FM: Fertőhomok É, a Palatinus-csatorna melletti, félszáraz gyeppel szomszédos facsoportban (KG, 2008) [8366.4]. KS: Magyarkeresztúr D, Fölerdőmajor mellett, keményfás-ligeterdő származékában, számos példány (KG, 2003) [8568.2]; Szil D, kavicsbányató mellett, akácos-kőrisesben ültetve (KG, 2004) [8569.1]. Szubmediterrán elterjedésű domb- és hegyvidéki faj, amelynek első kisalföldi adatait a Szigetközből KEVEY (1989) és WERNER (1990) közölték, majd KEVEY (2004c) egy hansági, RIEZING (2012a) egy Kocs melletti lelőhelyről tudósított. A Kisalföld burgenlandi oldaláról WALLMANN \& STINGL (2011) térképe jelez néhány telepített állományt. Ezen előfordulások őshonossága megkérdőjelezhető (telepítését, majd az állományok spontán terjeszkedését az ország több tájáról jelezték, vö. KIRÁLY 2001, SCHMIDT \& LENGYEL 2008, MOLNÁR \& CzÚCZ 2009), de a Szigetköz egyes részein (például Halászi, Derék-erdőben, Carex alba tömeges előfordulásával) nem is zárható ki. A fent felsorolt új lelőhelyei esetében nem valószínű az őshonosság, közlésüket azért tartjuk fontosnak, mert jelentős egyedszámú, viszonylag idős (több évtizedes korú) állományokról van szó, ahol a faj jól újul, és a környezetükben további spontán terjedése várható.

Gypsophila × digenea Borb. (= G. arenaria Waldst. et Kit. × paniculata L.) - GYT: Győr, Likócs DK, az M19 úttól D-re, homoki erdőssztyep mozaikban (KG, 2011) [8272.3]. - A taxont Borbás Vince 1888-ban Rákoson gyüjtött példány alapján írta le (BoRBÁs 1890), 
később Pest térségében és a Duna-Tisza köze más homokterületein ismételten gyűjtötték (SzujKó-LACZA 1993, BP: számos lap). Ezen kívül egy említése ismert a Győrszentiván melletti homokterületről („inter parentes”, PoLGÁR 1941; itteni 1908-as gyüjtéséből „Esztergelő-puszta” megjelöléssel 3 herbáriumi példányt találtunk: BP54957, BP426672, BP257161). Mostani jelzésünk a taxonról feltehetően nagyjából ugyanarra a lelőhelyre vonatkozik, ahol Polgár is találta. A területen mindkét szülőfaj nagy számban megtalálható, így a hibrid ismételt kialakulására jó esély mutatkozik.

Helictotrichon adsurgens (Schur ex Simonk.) Conert - HA: Lébény Ny, Pintér-Hany, kisebb „görönd" félszáraz gyepében (KG - TG, 2011) [8269.4]. GYT: Győrr, Ivánháza-pusztától ÉKre jó állapotú homokpusztagyepekben (KG, 2012) [8272.4]; Nagyszentjános, M1 csomópont melletti homoki rét/mocsárrét átmenet (KG, 2011) [8373.1]. PDS: Felpéc, Sísek, homoki réten (KG, 2006) [8471.3]. - Bonyolult taxonómiájú csoport tagja, ahol a régi adatok újraértelmezését a folyamatosan változó nevezéktan, valamint az egymástól eltérő rendszerezések is nehezítik. Soó (1973) munkájából a „H. pratense” kisalföldi említése bizonyára erre a fajra vonatkozik, ahogy PolGár (1941) győri (Miska-domb) „Avena pratense" adata is. Újabban ScHMIDT (2010) a bőnyi Sínai-hegyről közli, ahol a szerzők is megfigyelték. Győr környékén homoki élőhelyeken valószínűleg még többfelé előfordul. A fenti felsorolásban külön figyelmet érdemel hansági előkerülése, mivel a tájegységen csupán igen kevés és elszigetelt félszáraz gyep ismert.

Hottonia palustris L. - FM: Fertőboz ÉNy, csatornában (KG, 2008) [8366.3]. - A Kisalföld több területéről régóta ismert, a Hanságból és Tóközből (Csornai-sík É-i része) különösen sok helyről jelezték, de akadnak adatai a Szigetközből, sőt, a Győr-Tatai-teraszvidékről is (vö. KORNHUBER 1885, GOMBocz 1906, ZólYOMI 1934, PolGÁr 1941). A Hanságban (ellentétben CSAPODY 1975 a faj eltűnését sejtető bejegyzésével) ma is számos lelőhelye ismert, de megvan a Szigetközben és a Tóközben is (Takács G. ined.). A Fertő-medencéből korábban sohasem jelezték, itt egy tőzeges vizü csatornából került elő (Myriophyllum spicatum és Utricularia vulgaris társaságában).

Hypericum dubium Leers - KS: Himod D, a Gyóró felé vezető közút mellett, leromlott üde gyepben néhány tő (KG - LA, 2014) [8468.3]; Himod ÉK, Iharosi-erdő, keményfás ligeterdő felújításán néhány tő (KA - KG, 2002) [8468.3]; Hövej ÉNy, Kardos-ér mellett, „Irtás”, kőrises ligeterdő szélén néhány tő (KG, 2005) [8468.1]. - A Nyugat-Dunántúl üde kaszálórétjeinek jellegzetes faja, erős állományai a határszéli, humid klímájú területeken (például Sopron és Kőszeg térsége, Őrség) ismertek, de kisebb számban a Kisalföld pereméig előfordul (KIRÁLY et al. 2007). Fenti jelzései szintén a határterületről, de már egyértelmúen a Rábaköz (Kapuvári-sík) lapályáról származnak, ahol a klimatikus körülmények miatt már csak gyengén fejlett egyedek kis egyedszámú előfordulásait láttuk.

Juncus maritimus Lam. - FM: Fertőszéplak és Sarród, a Lászlómajortól Ny-ra, a Körgáttól Dre fekvő, legeltetett szikes rét-tömbben (mintegy 300 ha-os területen elszórtan) több ezer tő, helyenként társulásalkotó (KG, 2008-2014) [főleg 8366.2, kisrészt 8367.1]; Hegykő É, nádas-kékperjés réten, néhány tő (legnyugatabbi, elszigetelt előfordulása a hazai oldalon) (KG, 2008) [8366.4]; Sarród, Fertőújlak, Ürge-domb közelében az országhatáron, néhány tő (KG, 2008) [8366.2]; Sarród, Fertőújlak, Cikes É, nádasodó szikes réten, néhány tő (KG, 2008) [8267.3]; Sarród, Nyárliget É, az országhatár közelében, egykori kavicstó (ma horgásztó) partján, agyagos nyílt foltokon, néhány tő (legkeletebbi, elszigetelt előfordulása a hazai oldalon) (KG, 2004-2006) [8367.1]. - Tengerparti sós rétek növénye, Kárpátmedencei előfordulásai unikálisak, valószínúleg reliktum eredetűek. Magyarországon jelenleg a Fertő-medencében és a Balaton déli partján ismert, további lelőhelyei kérdésesek (vö. Soó 1973, 1980). CSAPODY (1975) PILL (1916) flóraművét jelöli meg az első fertői adat közléseként, valójában a faj nem kerül említésre e munkában. A Fertő mellől JÁvorKA (1923) jelezte elsőként, de feltehetően ma Burgenlandhoz tartozó területről, Mosonbán- 
falva (=Apetlon) mellett, az országhatár közelében. Jávorka nyomán az 1920-as években a Fertő mellől több szerző gyűjtötte (lásd BP), helymegjelöléseik szintén osztrák területre utalnak, egy kivétellel: Eszterháza (=Fertőd), Wágner J., 1925, BP332581. A későbbiekben egyetlen olyan adatáról sem tudunk, ami újra megerősítené előfordulását magyar területen egészen FARKAS (1999) közléséig (Fertőújlak: Mekszikópuszta). A „lappangás” oka egyszerú: a lelőhelyek a határszéli-határsávi, sokáig elzárt területen helyezkedtek el. Aktuális felmérésünk szerint egy nagy kiterjedésű állománya van a Lászlómajor közelében fekvő területrészen, ezen kívül néhány kisebb szórványa ennek 5 km-es körzetében. A közeli osztrák területeken csupán néhány kis egyedszámú állománya ismert, „tradicionális” Apetlon melletti élőhelyét tönkretették (WEBER 1989, MELZER \& BARTA 2005). A hazai fertői előfordulások (a nyárligeti kavicstó kivételével) erősen legeltetett szikes mocsarakban találhatók, Juncion maritimi-jellegű társulásban. Az élőhely gazdag tengerparti vagy kontinentális sztyepi sótűrő fajokban (például Carex extensa, Scorzonera parviflora, Taraxacum bessarabicum, Triglochin maritimum, lásd LÁJER 2006 és KIRÁLY et al. 2013, cönológiai felvételekkel). Egyes felvételekben az élőhely feltételezhető lápréti eredetére utaló fajok (Molinia caerulea s.l., Schoenus nigricans) is megtalálhatók. Nyárligeten taposott tóparton Agrostis stolonifera, Carex distans, Centaurium littorale mellett nő.

Knautia drymeia Heuff. - CS: Szany K, a Móricz-erdő ÉNy-i felében, keményfás-ligeterdő származékban számos tő (KG, 2004) [8569.2]. - A Kisalföldön a Rábától É-ra csak a Szigetköz egy pontján ismert (Hédervár - KEvEy 1989), így a szanyi lelőhely különös jelentőségü; a Kapuvári- és Csornai-sík hasonló erdeiben sokéves keresés ellenére nem találtuk meg. Bár a faj elég könnyen telepíthető, érdekes kísérői (Arum maculatum, Galium odoratum, Scilla vindobonensis, Viola alba) alapján az előfordulást egyértelműen őshonosnak véljük.

Lathyrus sphaericus Retz. - SZK: Dunakiliti, a (használaton kívüli) duzzasztómútől É-ra fekvő szigeten (Fazekas-zátony), kavicsos talajfelszínű bokorfüzesben (KG, 2009) [8069.2]. - Magyarországon döntően a mészkő- és dolomithegységek sziklagyepjeinek növénye, az Alföldről korábban ismeretlen volt (vö. Soó 1980, SIMON 2000, KIRÁLY 2009). A területre talán a Duna közvetítésével érkezett, erre utalnak kísérőnövényei (például Chamaenerion dodonaei, Isatis tinctoria, Salix elaeagnos), ill. a Szigetközből korábban jelzett szubalpin fajok, mint Primula elatior (Zólyomi 1937), Arabis alpina (KeVEY 1995) vagy Stellaria nemorum (KEVEY 1993, 1995) rövid életű előfordulásai. Nem zárható azonban ki a véletlen behurcolódás (például kőanyaggal a Dunántúli-középhegységből) sem, mivel Ausztriában csak pár, behurcoltnak vélt előfordulása ismert (FISCHER \& NIKLFELD 2011), ill. Szlovákiában is csupán egyetlen helyen - Dévény mellett - került elő (CHRTKová \& PENIAŠTEKová 1988).

Limonium gmelinii (Willd.) Kuntze - FM: Sarród, Fertőújlak, „Cikes”, mézpázsitos-tippanos réten, néhány tőből álló kis csoport; információink szerint szándékosan (a Hortobágyról behozott magok elvetésével) létrehozott állomány (KG - TG, 2003-2013) [8367.1]; IKM: Mocsa, a községtől D-re az M1 autópálya középső sávján, spontán betelepedés (KG - KA, 2015) [8375.3]. - A Nagyalföld egyes részein a szikes rétek jellegzetes, tömeges állományalkotó növénye, amelynek néhol terjeszkedését is megfigyelték antropogén élőhelyeken. A kisalföldi előfordulásával kapcsolatos leírások ellentmondásosak: Soó (1970) szerint a Kisalföldön csak a határon túl (azaz Burgenlandban) található meg, ezzel szemben az osztrák flóraművekben előfordulásának nincs nyoma (vö. JANCHEN 1977, FISCHER et al. 2008). CSAPODY (1975) következő adatát közölte: „Hegykő és Hidegség között szolonyec sziken", valószínúleg ennek nyomán Soó (1980) már a hazai Kisalföldről is megemlíti. Csapody megfigyeléséhez hozzátartozik, hogy a helymegadás illogikus (a két falu között fekszik Fertőhomok, nehezen érthető, hogy miért nem lokalizált pontosabban), ráadásul a megadott térségben a 2000-es években elvégzett vegetációtérképezések alapján szikes rétek nincsenek, különböző típusú láprétek és degradátumaik a jellemzőek. Emiatt (bár 
maga a faj eltéveszthetetlen) ezt az adatot erős fenntartással kezeljük, s mivel a fertőújlaki lelőhelyen, valamint az M1 autópályán bizonyosan adventív a faj, valószínűnek véljük, hogy a Kisalföldön nem voltak őshonos populációi.

Lycopsis arvensis L. - MS: Jánossomorja É, a volt Kápolna-tanya közelében, vadföldön és száraz szántószegélyben (KA - KG, 2002-2013) [8168.4]. - Országszerte ritka szegetális gyom, amelyet Soó (1968) jelez a Kisalföldről, de a régi irodalomban csak egy bizonytalan adatot találtunk róla PoLGÁr (1941) monográfiájában. Újabban PINKE \& PÁL (2001) Rajka mellett (szintén a Mosoni-síkon) találták meg, SCHMIDT \& BAUER (2005) Bábolna mellől közli. A fenti lelőhelyen több mint 10 évig ismétlődően, bár erősen ingadozó számban felvételeztük, Adonis aestivalis, Ajuga chamaepitys, Nigella arvensis társaságában.

Melampyrum cristatum L. - KS: Bogyoszló Ny, Petlendi-erdő, fiatalos melletti nyiladékon (KG, 2003) [8468.2]; KS: Bogyoszló Ny, Petlendi-erdő, keményfás ligeterdőbe ágyazódó platórész füves tölgyesében (KG, 2005) [8468.4]. - Száraz erdőszegélyek növénye, amelynek a Kisalföldön igen kevés potenciális élőhelye van. PoLGÁR (1941) a Csornai-sík É-i peremének több pontjáról (Pinnyéd, Gyirmót, Enese) jelezte. A Bogyoszló mellettihez hasonló szituációban fordul elő Vitnyédnél (KIRÁLY et al. 2007), már a Répce-síkon. A lelőhelyek térségében már a lapályi keményfás erdők a meghatározóak, azonban néhány kisebb plató formájában a rábaközi kavicstakaró még a felszínen is megjelenhet. Itt füvesedő kocsányos tölgyesekben más, erősen kötött talajt jelző fajokkal (például Agrostis capillaris, Dianthus armeria, Hieracium sabaudum, Pseudolysimachion orchideum, Trifolium medium) együtt fordul elő.

Moenchia mantica (L.) Ehrh. - CS: Árpás, a Rába-töltésén a közúti hídnál (KG - SD, 2013) [8470.3]; Egyed DNy, Emma-dűlö, a Buga-csatorna menti jellegtelen üde réteken hatalmas tömegben (KG, 2004) [8469.4]; Marcaltő É, a „Rábahíd” nevü vasúti megállónál, útszélen (KG, 2004) [8570.3]; Rábaszentandrás D, a Rába-híd lábánál fekvő réten (KG, 2004) [8570.3]; Sobor ÉK, a Rába védőtöltésén, másodlagos gyepben (KG, 2004) [8570.1]. KS: Himod D, a Gyóró felé vezető közút m., leromlott üde gyepben (KG - LA, 2014) [8468.3]; Rábakecöl D, a Kapuszegi-erdő mellett a Rába-töltésen (KG, 2004) [8568.4]; Vág É, a Páli felé vezető közút melletti mezsgyéken (KG, 2004) [8569.1]. - Szubmediterrán jellegű faj, hazai elterjedési centruma a Dél- és Délnyugat-Dunántúlon van. Elterjedésének egyes nyúlványai a Kisalföldet is elérik, PoLGÁR (1941 és BP) Gyirmót és Győrszemere mellől, azaz a Rába árterével szomszédos területekről jelezte, itteni őshonosságát Soó (1970) nem vonta kétségbe. Mai előfordulásai is részben kötődnek e vízfolyások töltéseihez, a gátak száraz-félszáraz másodlagos gyepjeiben több gazdag állományt ismerünk (jellemző kompozíció: Anthoxanthum odoratum, Campanula patula, Cerastium spp., Festuca rupicola, Gagea pratensis, Ornithogalum umbellatum agg.).

Plantago indica L. - FM: Fertőszéplak, „Széplaki-legelő”, degradált homoki gyepekben (KG, 2008) [8366.4]. - A faj a hazai homokvidékek jellemző növénye, ennek megfelelően Győr térségében és a várostól K-re régóta ismert (vö. PolGÁR 1941), ma szórványos előfordulású. A Fertö-medencéből egyetlen bizonytalan adata van („Fertőhomok körül” - KORNHUBER 1885; ez lehet, hogy az Ikva-teraszra vonatkozó megfigyelés). Új lelőhelye, a Fertőszéplaktól É-ra fekvő homokos legelő növényzete ma már erősen degradált, de nyomaiban (például Carex liparicarpos, C. stenophylla, Cruciata pedemontana, Medicago minima, Trigonella monspeliaca előfordulásával) még emlékeztet egykori fajgazdagságára.

Potamogeton coloratus Hornem. - HA: Lébény Ny, Bormászmajortól DNy-ra 0,9 km-re, sekély vízú csatornában, jelentős tömegben (KG, 2012) [8270.3]. - Tiszta vizű forráslápok, karsztvizes kifolyók ritka növénye, amelynek BAUER (2006) foglalta össze hazai adatait. A Hanságból (egyben az egész Kisalföldről) három régi előfordulását ismerteti a Lébény és Jánossomorja közötti lápmedencéből (a legfrissebb említés Soó 1934 dolgozatára utal). Tekintve, hogy az ún. Észak-Hanságban még ma is számos jó állapotú, lápi vizű csatorna 
található, várható volt, hogy a faj még előkerül a lápmedencében. Az új lelőhelyen (ami nagyvonalakban meg is egyezhet ZóLYomi ap. Soó 1934 „Lébény, Ottó-major” helymegnevezésével) egy nehezen megközelíthető, nagyon nehezen járható, erősen nádas mederszakaszon fordul elő, részben iszapos, nyílt felszínen, részben 5-15 cm mélységü, igen lassan áramló vízben, Eleocharis acicularis és Myriophyllum verticillatum társaságában. Az élőhely sérülékeny, a csatorna kikotrása a teljes állományt eltüntetheti, de a nádasodás, kezelés hiányában, a faj visszaszorulását is eredményezheti.

Quercus petraea (Matt.) Liebl. - GYT: Győr, Győrszentiván ÉNy, a temető mögötti homoki erdőssztyep-tölgyes foltban, számos $Q$. robur egyed mellett egy tipikus megjelenésű, nagy, terebélyes fa (KG - TG, 2011) [8272.3]. KS: Bogyoszló K, Tölös-erdő É-i részén, állományszerűen (valószínűleg telepítve) (KG, 2003) [8469.1]; Bogyoszló Ny, Petlendi-erdő, keményfás ligeterdő és füves tölgyes átmenetében néhány egyed (KG, 2003) [8468.4]; Hövej ÉNy, Kardos-ér mellett, „Irtás”, kőrises ligeterdőben néhány egyed (KG, 2005) [8468.1]. - A Kisalföld hazai részét övező dombvidékek jellemző, bár a Quercus cerris és $Q$. robur fajokkal szemben inkább alárendelt szerepet játszó fafaja, magáról a nagytájról viszont nem találtuk korábbi jelzését. A felsorolt lelőhelyek közül Bogyoszlótól K-re bizonyára ültetett, viszont a többi ponton nem zárható ki spontán megjelenése sem.

Salix × parviflora Host (= S. purpurea L. × rosmarinifolia L.) - GYT: Győr, Győrszentiván ÉK, a katonai lőtér (egyben LIFE terület) DNy-i sarkán, homoki élőhelykomplexumban (KG, 2013) [8272.4]. CS: Ikrény ÉK, a községhatár közelében, a vasúttól D-re fekvő kékperjéscserjés sávban (KG, 2012) [8371.1]. - PoLGÁR (1941) Győr térségéből három helyről említi, ezeken számos herbáriumi példányt gyüjtött (BP). A taxon szerepel Soó (1970) felsorolásában a Salix nemzetség hibridjei között, de konkrét hazai adat említése nélkül. Mindkét aktuális lelőhelyén leromlott kiszáradó lápréteken vagy azok szélein került elő néhány példánya, a szomszédos élőhelyfoltokon pedig mindkét szülőfaj előfordult. Az ikrényi előfordulás új, míg a győrszentiváni akár azonos is lehet Polgár „Haraszt-erdő” helymegjelölésű lelőhelyével. E nehezen észrevehető és azonosítható taxon archív adatai jó példák Polgár kivételes fajismeretére és megbízhatóságára.

Salix pentandra L. - HA: Csorna, Nyirkai-Hany élőhelyrekonstrukciós terület, a Kis-Metszés csatorna mellett, töltésoldalban számos példány (KA - KG - TG, 2009) [8269.3]. - A Hanság lápjainak fontos reliktumnövénye (előfordult Mosonszentjános és Királytó térségében is), amely azonban az élőhelyek közvetlen lerombolásával (pl. nemesnyár-ültetvények létrehozása), vagy fokozatos kiszáradásával eltűnt a területről, utolsó biztos jelzése Boros Ádám 1952-es gyújtése a Királytó közelében (ZóLYOMI 1931b, 1934, GenCSI 1999). A fenti lelőhelyen nagy meglepetésre került elő számos, virágzó-termő példányban, de később biztossá vált (az előfordulás jellege alapján már a terepen is valószínűnek tűnt), hogy az állomány egy hiányosan dokumentált visszatelepítési akciónak köszönhető.

Senecio sarracenicus L. - GYT: Nagyszentjános D, az M1 autópálya-csomóponttól É-ra fekvő jó állapotú homoki gyepek lábánál, nedves mélyedésben egy sarjtelep (KG, 2011) [8373.1]. - Ritka ligeterdei elem, amelyet a Szigetközben több ponton ma is előfordul, s élőhelyi indikációjának köszönhetően a Senecioni sarracenici - Populetum albae társulás névadó faja (KEvEY 2008). Győr térségében SCHMIDT (2010) egyetlen lelőhelyét említi (Győr, Bécsi úti nádas). A fent közölt lelőhely egy régen kiterjedtebb magassásos-kékperjés komplexum szélén található. A közelben előfordul még Carex elata, Euphorbia palustris, Sanguisorba officinalis, de a Senecio-lelőhelyen más higrofil fajoknak nyoma sincsen; itt a faj valószínúleg vegetatív telepe révén maradhatott meg, virágzását sohasem láttuk.

Stellaria palustris Retz. - HA: Acsalag K, a Kapuvár-Bősárkányi-csatorna hídja közelében, magassásosban, $1 \mathrm{~m}^{2}$-es foltban (KG, 2004) [8369.1]; Maglóca D, a Sziget-erdőtől K-re, Csorna-Maglócai-csatorna szegélyében néhány tő (KG, 2004) [8369.2]. - Feltöltődő holtágak, mocsarak, láperdők országszerte eltűnőben lévő növénye, amelynek hansági 
előfordulását többek közt KoRNHUBER (1885), ZóLYOMI (1934) és PoLGÁr (1941) említik; sőt, utóbbi szerző néhány helyen Győr mellett, a Szigetközben és a Tóközben is megtalálta. Megdöbbentő mértékű visszaszorulása miatt a faj minden aktuális adata nagy természetvédelmi jelentőséggel bír, s közlésre érdemes.

Stipa pennata L. - FM: Fertőszéplak, a „Széplaki-legelő” É-i peremén, másodlagos homoki gyepben (TG, 2001) [8366.2]; Sarród, Lászlómajortól Ny-ra fekvő jellegtelen homoki gyepekben (KG - TG, 2001) [8367.1]. HA: Lébény Ny, Pintér-Hany, kisebb „görönd” félszáraz gyepében (KG - TG, 2011) [8269.4]. - A Fertőmelléki-dombsor sztyeprétjein (a Nyugat-Dunántúl peremén, CSAPODY 1975), valamint a Győr környéki homokterületeken (POLGÁR 1941, FARKAS 1999) gyakori, jellegzetes faj, ezen kívül egy lelőhelyen a Szigetközben is előkerült (WERNER 1990). A Fertő-medence és a Hanság területén azonban nincs ősi, természetes élőhelye, itteni, újabban felfedezett előfordulásai a lecsapolás következtében szárazzá váló homoklepleken történő másodlagos megtelepedéssel magyarázhatók. A felsorolt helyeken homoki specialista fajok nem fordulnak elő, az érdekesebb kísérők általános száraz gyepi növények (például Potentilla arenaria, Silene viscosa, Vincetoxicum hirundinaria, Viola hirta).

Suaeda prostrata Pall. és S. pannonica (Beck) Graebn. - FM: Fertôszéplak és Sarród, a Lászlómajortól Ny-ra, a Körgáttól D-re fekvő, legeltetett szikes rét-tömbben, csak $S$. prostrata, taposott szikes gyepekben (KG, 2008-2013) [8366.2 és 8367.1]; Sarród, Fertőújlak, Cikes, mindkét faj, taposott szikes gyepekben (KG 2008-2013) [8367.1]. - A Suaeda nemzetség képviselői obligát sótűrő fajok, közép-európai taxonjaik rendszerezése sokáig tévúton haladt, amelyre FREITAG et al. (1996) hívták fel a figyelmet, majd a hazai viszonyok feltárása MILE \& WALTER (2003) nevéhez fűződik. Utóbbi szerzők tisztázták a Kárpát-medencei fajok elterjedését, a Fertő-medencéből a fenti két faj előfordulását jelezve. A S. pannonica és S. prostrata a Fertő tószögi (Seewinkel) szoloncsák szikesein helyenként tömeges, jellegzetes társulásalkotók (WENDELBERGER 1943). A magyar oldalon gyakorlatilag SZONTAGH (1864) balfi „Suaeda maritima” adata az egyetlen, amely biztosan hazai területre vonatkozik (megjegyezzük, hogy MILE \& WALTER (2003) a hazai Fertő-oldalra is megadják mindkét fajt, de BP herbáriumába kizárólag burgenlandi lapokat helyeztek el). Aktuális tapasztalataink szerint a területen a két faj általában együtt, csak néhány folton, alacsony példányszámban fordul elő. Igazán természetes élőhelyük nincs, a marhával legeltetett területrészek legerősebben taposott, a talajfelszínen sókiválásos részein bukkannak elő.

Thrincia nudicaulis (L.) Dostál - FM: Fertôszéplak és Sarród községhatárban, a Lászlómajortól Ny-ra, a Körgáttól D-re fekvő, legeltetett szikes rét-tömbben (mintegy 300 ha-os területen), helyenként tömeges (KG, 2003-2014) [8366.2 és 8367.1]; Sarród, Fertőújlak, Ürge-domb melletti gyepek (KG, 2009) [8366.2]. MS: Mosonmagyaróvár Ny, kavicstó az 1 sz. úttól É-ra (KG - PGy, 2007) [8169.1]. SZK: Lipót, kavicstó a Gombócosigátőrháztól D-re (KA - KG - PGy, 2007) [8170.4]; Lipót, a termálfürdő melletti csatorna és holtág partja (KA - KG - PGy, 2007) [8170.2]. - Terjedőben lévő, lelőhelyei egy részén feltehetően adventív faj. PoLGÁR (1941, ill. BP: számos gyüjtés) Győr térségében több helyen találta, feltehetően JEANPLONG (1972) bobai adata is a Kisalföldre vonatkozik. Újabb megfigyeléseit Győr térségéből SCHMIDT (2010) közölte, a Fertő-medencében a faj LÁJER (2006) sarródi Astero pannonici - Schoenetum nigricantis felvételeiben szerepelt. A Szigetközből még nem publikálták, de ismert az 1990-es években Felföldy által gyűjtött több példánya (Dunaszeg, Lipót, BP). Érdekes, hogy az országos flóramúvek közül Soó (1980) és SimON (2000) a fenti jelzések ellenére egyetlen kisalföldi megfigyelését sem említette. Ahogy az ország többi részén, a Kisalföldön is három alapvető élőhelytípusban találkozhatunk vele: (1) kiszáradó, leromló kékperjés réteken; (2) mesterséges tavak, holtágak nedves parti fövenyén; (3) vetett gyepekben, nyírt pázsitokban, új utak mellett vagy települések belterületén. 
Tordylium maximum L. - MM: Egyházaskesző D, a mezőgazdasági teleptől 1 km-re D-re a Marcal hídjánál, gyomos, jellegtelen gyepben, cserjés szélén (KG, 2013) [8669.2]. - A Kisalföldről korábban nem jelezték, viszont a Kemeneshát északi, ellaposodó nyúlványának tufakibúvásain többfelé előfordul (archív és recens adatait lásd MESTERHÁzY et al. 2003), feltehetően onnét került le a közeli Marcal menti területekre. Némileg hasonló szituációban, de már a Nyugat-magyarországi peremvidéken él a Répce-sík néhány pontján (KIRÁLY et al. 2007).

Trifolium medium Grufbg. in L. - KS: Babót, Babóti-erdo, nyiladékokon, napos erdőszegélyekben többfelé (KA - KG, 2002) [8468.2]; Bogyoszló Ny, Petlendi-erdő, keményfás ligeterdő napos nyiladékán (KG, 2005) [8468.4]; Rábakecöl D, a Rába töltésén (KG, 2004) [8568.4]; Kemenesszentpéter ÉNy, a Rába töltésén belül, hepehupás ártéri felszíneken, száraz cserjésben (KG, 2004) [8569.3]. - Fényben gazdag tölgyes társulásokban és szegélyeikben, hegyi réteken a középhegységekben és dombvidékeken jellemző faj. A Kisalföldön csupán POLGÁR (1941) két Győr melletti adatáról (Győrsziget, Kisbajcs) tudunk. Új előfordulási adatai a Rábaköz peremrészéről származnak, ahol a Répce-síkról átnyúló száraz tölgyes elemek sorába illeszkedik (az itteni fajkompozíció leírását lásd a Melampyrum cristatum-nál!).

Viola ambigua Waldst. et K. - MS: Várbalog DK, mosonszolnoki kavicsút kereszteződése közelében, útmenti gyepsávon számos tő (KA - KG, 2005) [8168.4]; Várbalog, Albertkázmérpuszta K, az A40 jelű határkő melletti száraz gyepen, többtucat tő (KA - KG, 2005) [8168.4]. - A Kisalföld keleti részének löszös gyepjeiben és erdeiben többfelé előfordul (RIEZING 2011, 2012b), legnyugatabbi jelzései Győr mellettiek (PolGÁR 1941). A Mosoni-sík területén található löszgyepekben az utóbbi években került elő, itteni állományát az élőhelyfragmentáció és a keskeny gyepsávokkal szomszédos mezőgazdasági területek igen intenzív művelése nagymértékben veszélyezteti. Legérdekesebb kísérőfajai a területen az Astragalus austriacus, Hesperis tristis, Marrubium peregrinum, Taraxacum serotinum, Thalictrum minus, Tunica saxifraga.

\section{Köszönetnyilvánítás}

A szerzők itt szeretnének köszönetet mondani a módszertani fejezetrészben felsorolt kollégáknak a közös terepbejárásokon nyújtott segítségért. Külön köszönjük Kevey Balázs (Pécs) és Schmidt Dávid (Sopron) információit és tanácsait egyes fajok előfordulásával, élőhelyi viszonyaival kapcsolatban. A szerzők Győr és Gönyű térségében végzett munkáját az Európai Közösség LIFE programjának pénzügyi támogatásával zajló Kisalföldi Life projekt (LIFE08 NAT/H/000289) monitoring eredményeinek felhasználása segítette.

\section{Irodalom}

BARINA Z. (2003): Adatok az esztergomi Duna-ártér flórájához. - Kitaibelia 8: 55-63.

BAUER N. (2006): A Potamogeton coloratus Hornem. Magyarországon. - Flora Pannonica 4: 111-119.

BorbÁs V. (1890): Gypsophila digenea n. sp. hybr. et G. arenariae W. et Kit. var. leioclados n. var. Természetrajzi Füzetek 13: 84-85.

Chrtková A. \& PeniašTeková M. (1988): Lathyrus L. - In: Bertová L. (ed.), Flóra Slovenska IV/4. VEDA, Bratislava, pp. 201-238.

CSAPody I. (1975): A Fertő-táj flórája és vegetációja. - In: Aujeszky L., Schilling F. \& Somogyi S. (eds), $A$ Fertő-táj Monongráfiáját előkészítő Adatgyüjtemény III. Vízgazdálkodási Tudományos Kutató Intézet, Budapest, pp. 1-420.

DöVÉNYI Z. (szerk.) (2010): Magyarország kistájainak katasztere. - Budapest, MTA Földrajztudományi Kutatóintézet, $876 \mathrm{pp}$.

Eliáš P. jun., DítĚ D., GRULICH V. \& SÁDovsKÝ M. (2008): Distribution and communities of Crypsis aculeata and Heleochloa schoenoides in Slovakia. - Hacquetia 7: 5-20. 
Elí̂́š P. jun., DítĚ D., MElečKovÁ Z. \& KIRÁLY G. (2011): Poznámky k výskytu vybraných zriedkavých druhov pol'ných depresií na Podunajskej nížine (juhozápadné Slovensko). Notes on the occurrence of some rare plant species of field depressions in the Podunajská nížina Lowland (SW Slovakia). Zprávy Česká botanická společnost 46: 265-276.

FARKAS S. (szerk.) (1999): Magyarország védett növényei. - Mezőgazda Kiadó, Budapest, 416 pp.

FisChER M. A. \& NiKLFELD H. (2001): Floristische Neufunde (51-56). - Neilreichia 1: 237-241.

FisCHER M. A. \& NiKLFELD H. (2011): Floristische Neufunde (99-123). - Neilreichia 6: 365-396.

FisCHER M. A., AdLER W. \& OSWALD K. (2008): Exkursionsflora für Österreich, Liechtenstein und Südtirol. Land Oberösterreich, OÖ Landesmuseen, Linz, 1392 pp.

FodoR L., PÁL-FÁM F. \& Rimóczi I. (2002): Szigetközi keményfa-ligetek mikológiai jellemzése. - Kitaibelia 7: 141-145.

Freitag H., Walter J. \& Wucherer W. (1996): Die Gattung Suaeda (Chenopodiaceae) in Österreich, mit einem Ausblick auf die pannonischen Nachbarländer. - Annalen des Naturhistorischen Museums in Wien 98B: 343-367.

GÁYER Gy \& POLGÁR S. (1926): Az Allium suaveolens Jacq. magyarországi előfordulása. - Magyar Botanikai Lapok 24: 109-111.

GENCSI Z. (1999): Babérfüz (Salix pentandra L.). - In: BARTHA D., BölÖNI J. \& KIRÁLY G. (szerk.), Magyarország védett és veszélyeztetett fa- és cserjefajai I. - Tilia 7: 55-59.

Gомвосz E. (1906): Sopron vármegye növényföldrajza és flórája. - Mathematikai és Természettudományi Közlemények 28: 401-577.

Holub J. \& Grulich V. (1999): Heleochloa alopecuroides (Piller \& Mitterp.) Host ex Roem. - In: ČEŘovsKÝ, J., FerÁKovÁ, V., Holub, J. \& ProcházKA, F. (eds), Červená kniha ohrozených a vzácnych druhov rastlín a živočíchov SR a ČR. 5. Vyššie rastliny. Príroda, Bratislava, p. 177.

Janchen E. (1977): Flora von Wien, Niederösterreich und Nordburgenland; 2. Auflage. - Verein für Landeskunde von Niederösterreich und Wien, Wien, 755 pp.

JávoRKA S. (1923): Két új adat hazánk flórájához. - Magyar Botanikai Lapok 21 [1922]: 67-68.

JEANPLONG J. (1956): Flóraelemek szerepe a flórahatárok megvonásában Északnyugat-Dunántúlon. Botanikai Közlemények 46: 261-266.

JEANPLONG J. (1972): Új adatok Északnyugat Dunántúl flórájának ismeretéhez. - Vasi Szemle 26: 586-588.

JEANPLONG J. (1983): Új adatok Északnyugat-Dunántıl flórájának ismeretéhez II. - Vasi Szemle 37: 111-114.

JEANPLONG J. (1991): Új adatok Északnyugat Dunántúl flórájának ismeretéhez III. - Vasi Szemle 45: 17-19.

KÁRPÁTI Z. (1958): A nyugat-dunántúli - burgenlandi flórahatárvonalakról. - Botanikai Közlemények 47: 313-321.

KÁRPÁTI Z. (1960): Die pflanzengeographische Gliederung Transdanubiens. - Acta Botanica Hungarica 6: 45-53.

KästNer A. \& Fischer M. A. (2006): Porträts ausgewählter seltener österreichischer Gefäßpflanzen (II): (5) bis (15). - Neilreichia 4: 75-109.

KäSTNER A. \& FisChER M. A. (2008): Porträts ausgewählter seltener österreichischer Gefäßpflanzen (III): (16) bis (30). - Neilreichia 5: 131-172.

KEVEY B. (1989): Adatok Magyarország flórájának és vegetációjának ismeretéhez V. - Botanikai Közlemények 76: 83-96.

KEvEY B. (1993): Adatok Magyarország flórájának és vegetációjának ismeretéhez VI. - Botanikai Közlemények 80: 53-60.

KEVEY B. (1995): Adatok Magyarország flórájának és vegetációjának ismeretéhez VII. - Botanikai Közlemények 82: 45-53.

KeveY B. (2001a): Adatok Magyarország flórájának és vegetációjának ismeretéhez VIII. - Botanikai Közlemények 88: 95-105.

Kevey B. (2001b): A Carex strigosa Huds. elterjedése Magyarországon. - Kitaibelia 6: 37-44.

KeveY B. (2002): A Duna szlovákiai elterelésének hatása a Felső-Szigetköz tölgy-kőris-szil ligeteire (Pimpinello majoris-Ulmetum Kevey in Borhidi \& Kevey 1996). - Kanitzia 9: 227- 249.

KeveY B. (2004a): A Duna szlovákiai elterelésének hatása a Felső-Szigetköz fehérnyárligeteire (Senecioni sarracenici-Populetum albae Kevey in Borhidi \& Kevey 1996). - Kanitzia 12: 177- 195.

Kevey B. (2004b): A Duna szlovákiai elterelésének hatása a Felső-Szigetköz fehér fűzligeteire (Leucojo aestivi-Salicetum albae Kevey in Borhidi \& Kevey 1996). - Kitaibelia 9: 173-186.

KevEY B. (2004c): Adatok Magyarország flórájának és vegetációjának ismeretéhez IX. - Botanikai Közlemények 91: 13-23. 
Kevey B. (2008): Magyarország erdôtársulásai. - Tilia vol. 14, 488 pp.

KEVEY B. \& AlEXAY Z. (1994): A Szigetköz dárdás-nádtippanos-füzlápjai (Calamagrostio-Salicetum cinereae). - Acta Agronomica Óváriensis 36: 7-22.

KIRÁlY A. \& KiRÁLY G. (2000): A Délnyugat-Kisalföld florisztikai - növényföldrajzi kutatásának előzetes eredményei. - Kitaibelia 5: 307-311.

KIRÁLY G. (2001): A Fertőmelléki-dombsor vegetációja. - Tilia 10: 181-303.

KIRÁLY G. (szerk.) (2009): Új magyar füvészkönyv. Magyarország hajtásos növényei. Határozókulcsok. Aggteleki Nemzeti Park Igazgatóság, Jósvafő, 616 pp.

Király G., Bidló A., TAKÁcs G., Eliáš, P. jun., MelečKová, Z. \& DítĚ, D. (2013): Remote locality of the litoral Carex extensa (Cyperaceae) in Hungary - long distance dispersal from coastal to inland salt marshes. - Biologia 68: 872-878.

KirÁly G., CSAPody I., SZMorad F. \& TímÁr G. (2004): A Soproni-hegység edényes flórája. Enumeráció. - In: KIRÁLY G. (szerk.), A Soproni-hegység edényes flórája. - Flora Pannonica 2: 91-481.

KiRÁlY G. \& KiRÁLY A. (1999): Adatok és kiegészítések a magyar flóra ismeretéhez. - Kitaibelia 4: 229-245.

KIRÁLY G. \& KirÁly A. (2006): Adatok és kiegészítések a magyar flóra ismeretéhez II. - Kitaibelia 10 [2005]: 88-103.

KirÁly G. \& KirÁly A. (2010): Molyhos nyír (Betula pubescens Ehrh.). - In: BARTHA D. (szerk.), Magyarország védett és veszélyeztetett fa- és cserjefajai II. - Tilia 15: 21-42.

KiRÁLY G., NAGY A. \& KirÁLY A. (2005): Kiegészítések a Soproni-hegység és a Soproni-medence flórájának ismeretéhez. - Flora Pannonica 3: 41-48.

KirÁLY G., MESTERhÁZy A. \& KirÁLY A. (2007): Adatok a Nyugat-Dunántúl flórájához és növényföldrajzához. - Flora Pannonica 5: 3-66.

KoRnhuber A. (1885): Botanische Ausflüge in die Sumpfniederung des „Waasen” (magyar. „Hanság”). Verhandlungen der zoologisch-botanischen Gesellschaft (Wien) 35: 619-656.

LÁJER K. (1997): A Marcal-medence déli részének lápi és lápréti növénytársulásai. - Kitaibelia 2: 281-289.

LÁJER K. (1998a): Az Aldrovanda vesiculosa L. újabb előfordulása és egyéb adatok Magyarország flórájának ismeretéhez. - Kitaiblia 3: 263-274.

LÁJER K. (1998b): Bevezetés a magyarországi lápok vegetáció-ökológiájába. - Tilia 6: 84-238.

LÁJER K. (2006): A Schoenus nigricans L. társulási viszonyairól Magyarországon. - Flora Pannonica 4: 77-90.

Melzer H. \& BARTA Th. (2005): Bromus hordeaceus subsp. thominei, die Strand-Weich-Trespe, neu für Österreich, ebenso sechs weitere Sippen und andere floristische Neuigkeiten aus Wien, Niederösterreich und Burgenland. - Linzer biologische Beiträge 37: 1401-1430.

MESTERHÁZy A., BAUER N. \& KULCSÁR L. (2003): A kisalföldi bazalt tanúhegyek edényes flórája. - Tilia 11: $7-165$.

Mile O. \& WALTER J. (2003): A Suaeda Forskål ex Scop. (Chenopodiaceae) nemzetség Magyarországon. Flora Pannonica 1: 29-43.

MolnÁr Cs. \& Czúcz B. (2009): A virágos kőris (Fraxinus ornus L.) terjedése és mai termőhelyei az Északi-középhegységben. - Botanikai Közlemények 96: 71-81.

PenKSZA K. \& Király G. (2009): Brachypodium P. Beauv. - In: Király G. (szerk.) (2009), Új magyar füvészkönyv. Magyarország hajtásos növényei. Határozókulcsok. ANP Igazgatóság, Jósvafő, pp. 519-520.

Pill K. (1916): Die Flora des Leithagebirges und am Neusiedlersee. - Leykam, Graz, 136 pp.

Pinke Gy. \& PÁL R. (2001): Adatok a Kisalföld gyomflórájának ismeretéhez. - Kitaibelia 6: 381-400.

PolGÁR S. (1941): Győrmegye flórája (Flora Comitatus Jaurinensis). - Botanikai Közlemények 38: 201-352.

RiEziNG N. (2002): Adatok a Dunántúl északi részének flórájához. - Kitaibelia 7: 163-167.

RIEzING N. (2005): Adatok a Gönyű - Neszmély közötti Duna-szakasz flórájához és vegetációjához. Botanikai Közlemények 92: 57-67.

RiEZING N. (2011): A Győr-tatai Kisalföld erdei: tájtörténet és vegetáció. - Tájökológiai Lapok 9: 209-217.

RIEZING N. (2012a): Adatok a Győr-tatai Kisalföld flórájához és vegetációjához. - Botanikai Közlemények 99: 81-102.

RIEZING N. (2012b): Maradványerdők a kisalföldi peremvidék erdőssztyep zónájában. - Tájökológiai Lapok 10: 371-384.

SchmidT D. (2007): A Győr környéki szikesek növényzete. - Flora Pannonica 5: 95-104.

Scнмidт D. (2010): Adatok a Kisalföld flórájának ismeretéhez II. - Botanikai Közlemények 97: 79-96.

ScнмiDT D. (2011): Kiegészítések a Kisalföld flórájához és vegetációjához. - Kitaibelia 15 [2010]: 109-117. 
SCHMIDT D. \& BAUER N. (2005): Adatok a Kisalföld flórájának ismeretéhez I. - Botanikai Közlemények 92: 43-56.

Schmidt D. \& Lengyel A. (2008): Adatok a Pannonhalmi-dombság flórájának ismeretéhez. - Flora Pannonica 6: 25-57.

Simon T. (1992): A magyarországi edényes flóra határozója. - Tankönyvkiadó, Budapest, 892 pp.

Simon T. (2000): A magyarországi edényes flóra határozója. 4., átdolgozott kiadás - Tankönyvkiadó, Budapest, $976 \mathrm{pp}$.

Somogyi J. (2001): Rozšírenie druhu Allium atroviolaceum Boiss. na Slovensku. - Bulletin Slovenskej botanickej spoločnosti 23: 107-110.

Soó R. (1964-1980): A magyar flóra és vegetáció rendszertani-növényföldrajzi kézikönyve I-VI. Akadémiai Kiadó, Budapest, 589 pp., 655 pp., $506+51$ pp., 614 pp., 724 p., 556 pp.

Soó R. \& Jávorka S. (1951): A magyar növényvilág kézikönyve I-II. - Akadémiai Kiadó, Budapest, 1120 pp.

SzONTAGH N. (1864): Enumeratio plantarum phanaerogamicarum sponte crestentium copiusque cultarum territorii Soproniensis. - Verhandlungen der zoologisch-botanischen Gesellschaft (Wien) 14: 463-502.

SZUjKó-LACZA J. (1993). Flowering plants in the Kiskunság National Park and the other region between the Danube and Tisza rivers. - In: SzujKó-Lacza J. \& Kováts D. (eds), The Flora of the Kiskunság National Park I. The flowering plants. Budapest, Magyar Természettudományi Múzeum, pp. 43-468.

WALLNER I. (1903): Sopron környékén található virágos növények és edényes cryptogamok nevei és fajai. -Soproni Állami Föreáliskola Értesítője, 42 pp.

Wallmann Th. \& STingl R. (2011): Die Blumen-Esche Fraxinus ornus am nördlichen Alpenostrand. Neilreichia 6: 183-296.

WeBER E. (1989): Die Burgenländischen Vorkommen der Meerstrandbinse (Juncus maritimus Lam.) und des Echten Haarstranges (Peucedanum officinale L.). - BFB-Bericht 71: 35-37.

Wendelberger G. (1943): Die Salzpflanzengesellschaften des Neusiedler Sees. - Wiener botanische Zeitschrift 92: 124-144.

WERNER E. (1990): A Felső-Szigetköz néhány botanikai értéke. - A mosonmagyaróvári Kossuth Lajos Gimnázium Évkönyve „1989-90”: 20-29.

Zólyomi B. (1931a): Adatok a Hanság flórájához. - Botanikai Közlemények 28: 191-192.

ZólYomi B. (1931b): A Kis-Alföld páfrányairól. - Botanikai Közlemények 28: 189-191.

ZólYomi B. (1934): A Hanság növényszövetkezetei. - Vasi Szemle 1: 146-174.

ZóLYomi B. (1937): A Szigetköz növénytani kutatásainak eredményei. - Botanikai Közlemények 34: 169-192.

Beérkezett / received: 2015. 03. 02. • Elfogadva / accepted: 2015. 03. 17. 